\title{
The influence of Palm Kernel Cake and Rice Bran Fermentation Product Mixture to the Broiler Carcass Quality
}

\author{
Yadi Priabudiman $^{\# 2}$ and Yana Sukaryana ${ }^{\# 2}$ \\ " Animal Husbandry-Lampung State Polytechnic, Jl.Soekarno-Hatta 10, Bandar Lampung, Indonesia.
}

\author{
1ps_tptepolinela.ac.id \\ ${ }^{2}$ yana1962@gmail.com
}

\begin{abstract}
The purpose of this research was to study the effect of the use of palm kernel cake (PKC) and rice bran (RB) fermentation products mixture to the percentage of broiler carcass weight pieces. Research using completely randomized design (CRD) with treatments of the fermentationproduct usage rate of $0 \%(\mathrm{P} 0), 10 \%(\mathrm{P} 1), 20 \%(\mathrm{P} 2), 30 \%(\mathrm{P} 3)$ and $40 \%(\mathrm{P} 4)$ of the total ration of 4replications. Variables meas ured were percentage of carcass weight ratio cut pieces of carcass weight (carcass front, rear carcass, breast meat, wings, back, and thigh)with carcassweight multiplied by $100 \%$. The results showed that the percentage of carcass weight piece front and rear carcass was shown at P3.
\end{abstract}

Keywords - palm kernel cake, rice bran, fermentation, pieces of carcass, broilers.

\section{INTRODUCTION}

Poultry feed requirements for Indonesia is very high, in accordance with the high poultry production. Some ingredients such as corn, soybean meal and fish meal are imported. The government has been encouraging animal feed factory that still uses a mix of imported feed ingredients, using local feed ingredients to lower feed prices in the country. In this regard, the search for alternative feed ingredients using agro industrial byproducts and wastes need to be done. Utilization of feed material making up rations that do not compete with human needs, which still has adequate nutritional value and, in terms of low cost economy so as to reduce the cost of rations. Alternative feed ingredients are enough potential to scale feed mills such as palm kernel cake (PKC) and rice bran (RB).

Palm kernel cake is a waste palm oil mills which its availability quite abundant and do not compete with human needs and not fully utilized as poultry feed ingredients. Feed ingredients derived from agro waste are usually very limited use for poultry rations, because these materials generally contain high crude fiber. Rice bran is a by-product of rice milling is very potentially be used as feed material which do not compete with human needs. PKC crude fibre content is quite high at 11.30 to $17.00 \%$ (Sukaryana, 2001), is necessary to consider its use as a broiler feed ingredient because it is difficult to digest (Siregar and Mirwandhono., 2004). The use of rice bran as feed material that is faced with constraints of low crude protein content of about $7.6 \%$ and the high content of crude fiber from 12.4 to $27.8 \%$ (Tillman et al., 2005), although both the energy content of $1510-1687 \mathrm{kcal} / \mathrm{kg}$ (Kumajas, 1997). Necessary efforts to overcome the weakness of the two materials through a fermentation process. Fermentation is one alternative method to enhance the nutritional value of a waste. Fermentation can also change the feed material are difficult to digest into easily digested, producing a distinctive aroma and flavor, and can eliminate toxins from the original material. Fermentation with the fungus Trichoderma viride has been widely used in various substrates, especially that containing high roughage such as PKC. These fungi live on a suitable substrate containing starch such as rice bran. BIS weaknesses that do not contain starch will be helped by the rice bran which contains starch; so that the substrate mixture is fermented PKC and RB will be optimal. The presence of starch in the substrate used by fungi as a source of energy for growth and development. Growth and development of a good mold fungus produces the enzyme cellulase spurred in large quantities that can be used to remodel and lower crude fiber. Cellulase is an enzyme that can decide $\beta$ glycosides bond (1.4) on cellulose. The high population of fungus can increase the crude protein content of the substrate as the mold is a source of single cell protein (Sukaryana, 2007). If the BIS is mixed with the DP is expected to be a suitable medium for the fungus to the occurrence of a good fermentation process by increasing the nutritional value.

Carcasses are part of the body after the cut and discarded chicken feathers, abdominal fat, organs, legs, head, neck and blood, except the lungs and kidneys (Rizal, 2006). According Lesson (2000), factors that affect the carcass weight is genetic and environmental factors. Environmental factors can be divided into two categories: physiological and content of nutrients in feed. Weights are influenced by the weight of the chicken carcass is cut (North, 1992). Percentage of carcass weight is calculated by dividing the carcass weight multiplied by $100 \%$ live (Rizal, 2006).

Chicken carcass composed of muscle tissue, adipose tissue or fat, and bone. In general, the main factors that determine the variation of meat is the size, gender, body conformation, and genetic chicken. Carcasses can be divided into two parts, namely the front of the carcass and carcass parts back. Pieces of carcass parts usually marketed commercially made from the thigh, chest, back and wings (Siregar et al, 1981). The average percentage weight of the chest on research Resnawati (2004) ie 24.13 to $26.79 \%$, the average weight of the wing from 24.13 to $26.79 \%$, the average weight of the back between 23.20 to $23.95 \%$, and the average weight of the thigh between 29.78 to $30.82 \%$. Percentage weight of the chest will increase 
with increasing body weight and carcass weight. In addition to the influence of feed, the developments of breast meat are also influenced by gender, age, genetic factors, and strains of chicken (Rezaei et al., 2004). Furthermore, Shanin and Abd El Azeem (2005) suggested that chicken carcasses fed with a high content of fiber, both with high or low protein content have the proportion of carcass weight with higher bone than the chickens fed with a low content of fiber, both with content high or low protein. The research was directed to how large the influence of various levels of mixed-use PKC - RB fermentation product of the percentage of broiler carcass weight pieces.

\section{RESEARCH METHOD}

Animal experiments are as much as 200 DOC broiler strain CP-707 tails produced by PT Charoen Pokphand Jaya Farm. Ration of a mixture of constituent materials PKC (80\%)-RB (20\%) fermentation products, fish meal, soybean meal, corn, rice bran, palm oil, and medicine. Treatment rations prepared with $22 \%$ protein content with the level of metabolic energy $3000 \mathrm{kcal} / \mathrm{kg}$. The composition of treatment rations are presented in Table 1.

This study used a complete randomized design (CRD) with a treatment level of use of fermentation as much as 0 (P0), 10 (P1), 20 (P2), 30\% (P3) and 40\% (P4) of the total feed with 4 replications. DOC at the research level of the fermentation is maintained in a sealed enclosure litter in accordance with the needs of the size $1 \times 1,5 \mathrm{~m} 2$ for each plot as many as 20 plots. DOC initially weighed and randomly divided into 20 equal groups, then randomly divided into 5 treatment of feed with 4 replications (each of 10 tails). Each group of chickens treatment (other than a control group who were given rations treated P0 $=100 \%$ of control feed) will be given feed treated with the best use of the fermentation is 10 (P1), 20 (P2), 30\% (P3) and $40 \%$ (P4) of the total feed. Chickens kept for 5 weeks and were given rations and drinking ad libitum. ND vaccine given at 3-day old chickens by eye drop and the age of 3 weeks through drinking water. At the end of the fifth week of chickens are slaughtered as many as 3 units $\mathrm{x} 4$ experimental replicates for each treatment to observation of carcass, abdominal fat and fat content of meat.

Observed variables are as follows: 1) The percentage of carcass weight is calculated by dividing the carcass weight multiplied by $100 \%$ life, 2) percentage is the percentage of carcass weight cut pieces of carcass weight (carcass front, the back of the carcass, breast meat, wings, back, and thigh) carcass weight multiplied by $100 \%$. The data were tabulated and analysed the results of various studies using Completely Randomized Design (Steel and Torrie, 1995). To find the difference between treatments, followed by Duncan's Multiple range test.

Table 1. Composition of Rations Research

\begin{tabular}{lrrrrr}
\hline Materials Ration & \multicolumn{5}{c}{ Research Ration } \\
\cline { 2 - 6 } & P0 & \multicolumn{1}{c}{ P1 } & \multicolumn{1}{c}{ P2 } & P3 & \multicolumn{1}{c}{ P4 } \\
\hline & & $\ldots \ldots \ldots \ldots \ldots \ldots \ldots$ & $\ldots \ldots \ldots \ldots \ldots \ldots$ \\
Fish Meal & 19,00 & 19,00 & 19,00 & 20,70 & 20,00 \\
Soybeans Cake & 10,00 & 7,50 & 4,75 & 0,00 & 0,00 \\
Yellow Corn & 62,00 & 59,50 & 55,25 & 47,30 & 35,50 \\
Rice Bran & 8,00 & 3,00 & 0,00 & 0,00 & 0,00 \\
Fermentation Products & 0,00 & 10,00 & 20,00 & 30,00 & 40,00 \\
Palm Oil & 1,00 & 1,00 & 1,00 & 2,00 & 4,50 \\
\hline Total & 100,00 & 100,00 & 100,00 & 100,00 & 100,00 \\
\hline
\end{tabular}

The tools used in the study were stable litter, feed and drink a set of tools, digital scales capacity of $210 \mathrm{~g}$ with a precision $0.001 \mathrm{~g}, 2 \mathrm{~kg}$ weight capacity of the cake with a precision 0.1 g, $5 \mathrm{~kg}$ capacity digital scales accurate to $0.001 \mathrm{~g}$, torch lights, thermometers, hygrometer, cage cleaning equipment, ovens, and a set of tools for analysis of fat content of meat.

\begin{tabular}{lrrrrrr}
\hline Materials Ration & \multicolumn{1}{c}{ CP } & CFat & CFib & ME & Lisin & Metionin \\
\hline & $\ldots \ldots \ldots \% \ldots \ldots \ldots$ & $(\mathrm{kcal} / \mathrm{kg})$ & $\ldots \ldots \ldots \%$ & $\ldots \ldots \ldots$ \\
Fish Meal & 59,50 & 11,00 & 0,10 & 3150,00 & 6,70 & 1,90 \\
Soybeans Cake & 42,00 & 1,00 & 4,00 & 2200,00 & 3,10 & 0,67 \\
Yellow Corn & 9,50 & 2,50 & 2,50 & 3250,00 & 0,21 & 0,19 \\
Rice Bran & 8,50 & 8,50 & 12,00 & 1600,00 & 0,80 & 0,30 \\
Fermentation & 17,34 & 5,35 & 23,67 & 2149,33 & 3,10 & 1,20 \\
Products & & - & - & 8600,00 & & \\
Palm Oil & - & - & & & - & - \\
\hline
\end{tabular}

Source: Animal Laboratory analysis Polytechnic Lampung (2010)

Table 3. Composition of The Rations of Food Substances Research

\begin{tabular}{lrrrrr}
\hline Food substances & \multicolumn{1}{c}{ P0 } & \multicolumn{1}{c}{ P1 } & P2 & P3 & \multicolumn{1}{c}{ P4 } \\
\hline C Protein (\%) & 22,08 & 22,10 & 22,02 & 22,01 & 22,21 \\
C Fat (\%) & 4,42 & 4,44 & 4,59 & 5,06 & 5,23 \\
C Fiber (\%) & 2,93 & 4,53 & 6,32 & 8,30 & 10,38 \\
ME (kcal/kg) & 3047,50 & 3046,18 & 3014,49 & 3006,10 & 3030,48 \\
Lisin (\%) & 1,78 & 1,96 & 2,16 & 2,42 & 2,65 \\
Metionin (\%) & 0,57 & 0,65 & 0,74 & 0,84 & 0,93 \\
\hline Description: The results from Tables 1 and 2 & & &
\end{tabular}

Description: The results from Tables 1 and 2

\section{RESULTS AND DISCUSSION}

Pieces of chicken broiler carcasses in this study were divided into the front of the carcass pieces of breast meat and wings, the back of the carcass pieces of thigh and back. Percentage of data bits of each carcass are presented in Tables 4 and 5.

Pieces of the front of the carcass are a carcass part which consists mainly of meat, while the carcass backs more of the bone than flesh. Usage rate of fermentation in the ration provides a significantly different effect $(\mathrm{P}<0.05)$ against the percentage of carcass cuts the front and rear. This is presumably because the content of live weight and carcass weight of chickens in each treatment was significantly different to produce pieces of carcass weight percentage (carcass front, back, breast meat, wings, thighs, back) are significantly different as well. The average percentage of carcass weight to the front piece on this study ranged from 26.96 to $30.62 \%$ and cut the back of the carcass between 33.90 to $36.14 \%$. The average percentage of carcass weight piece front and rear pieces of the highest carcass is shown in treatment P3. The percentage of carcass weight of the front of this piece was much lower than those reported Young et al. (2001) that the average percentage of carcass weight of piece on the front of broilers aged 37 days was 53.6\%.

Table 4. The percentage of carcass weight, carcass cut front, breast meat, and wings of each treatment

\begin{tabular}{|c|c|c|c|c|}
\hline Treatment & $\begin{array}{l}\text { Carcass } \\
\text { weight }\end{array}$ & $\begin{array}{c}\text { Carcass cut } \\
\text { Front }\end{array}$ & $\begin{array}{l}\text { Breast } \\
\text { Meat }\end{array}$ & Wings \\
\hline & & 0 & & \\
\hline P0 & 60,76 & 26,86 & 14,06 & 12,80 \\
\hline $\mathrm{P} 1$ & 62,43 & 27,81 & 14,48 & 13,34 \\
\hline $\mathrm{P} 2$ & 64,10 & 28,87 & 15,69 & 13,18 \\
\hline P3 & 67,76 & 30,62 & 16,83 & 13,79 \\
\hline $\mathrm{P} 4$ & 64,33 & 28,99 & 15,91 & 13,08 \\
\hline
\end{tabular}


Table 5. The percentage of carcass weight cut back, thighs, and back of each

\begin{tabular}{cccc} 
Treatment & & & \\
\hline Treatment & Weight Cut Back & Thighs & Back \\
\hline & $\ldots \ldots \ldots \ldots \ldots \ldots \ldots \ldots \ldots \ldots \ldots \ldots \ldots \ldots \ldots \ldots$ & $\% \ldots \ldots \ldots$ \\
P0 & 33,90 & 18,01 & 15,88 \\
P1 & 34,62 & 17,56 & 17,06 \\
P2 & 35,23 & 17,36 & 17,87 \\
P3 & 37,14 & 18,03 & 19,11 \\
P4 & 35,34 & 17,28 & 18,06 \\
\hline
\end{tabular}

The low percentage of carcass weight to the front piece in comparison with the literature allegedly apart from the technical aspects of the way and limits the cutting body parts are also caused by differences in chicken feed used. The amount used as benchmarks for assessing the quality of chest meat because most of the muscle which is the largest component of carcasses found around the chest. The development of breast meat mainly influenced by the protein content in feed rather than energy. Saleh et al. (1997) reported that there are no real differences in the characteristics and the percentage of pieces of carcass weight in chickens fed with an energy content between 3100-3400 kcal / kg. Resnawati (2004) states that the percentage weight of the chest will increase with increasing body weight and carcass weight. In addition to the influence of feed, the development of breast meat also influenced by gender, age, genetic factors, and strains of chickens (Rezaei et al., 2004). The average percentage weights of the wing in this study are from 12.80 to $13.79 \%$. The average percentage weight of the wing in this study was higher with the proposed Resnawati (2004), ie from 11.64 to $12.41 \%$, lower than reports and Nataatmijaya Stars (2006), ie from 15.32 to $16.97 \%$, and relatively higher than reported Saleh et al. (1997), ie from 11.24 to $11.73 \%$. This is probably due to energy and protein content in each feed are nearly the same treatment. Thigh is one of the commercial carcass pieces. Intact thigh consists of two parts, the upper thigh and lower thigh. In this study measured the percentage of the full weight of the thigh without separated into upper and lower thigh. The average percentage weight of the thigh in the study between 17.36 to $18.03 \%$. According Resnawati (2004) thigh is part carcass that contains a lot of meat so that its development is much influenced by the protein content of feed. Furthermore, Shanin and Abd El Azeem (2005) suggested that chicken carcasses fed with a high content of fiber, both with high or low protein content have the proportion of carcass weight with higher bone than the chickens fed with a low content of fiber, both with content high or low protein. Besides the obvious difference is also due to weight gain and carcass weights are significantly different as well. The average percentage of weight back on this study ranged from 15.88 to $19.11 \%$. Broiler backs almost entirely a boned whose development is more influenced by the content of $\mathrm{Ca}$ in the diet than protein or energy. Resnawati (2004) suggested that broiler backs contain more bone tissue, so that the mineral content in feed is more influential on the back compared to the weight of the protein. Instead Shanin and Abd El Azeem (2005) suggested that the feed does not affect the weight distribution of the bone. Suspected that the weight distribution of bone independent of the feed.

\section{CONCLUSIONS}

Based on this research can be concluded that the percentage of carcass weight to cut the front and the back of the highest carcass is shown in treatment $\mathrm{P} 3$.

\section{REFERENCES}

[1] Kumajas, 1997. Effect of Rice Bran Fermented with Trichoderme viride on Substances Food Ingredients and metabolizable energy on Broiler. Thesis. Padjadjaran University Graduate Program. Bandung.

[2] Lesson, S. 2000. Nutrition and Quality of Broiler Carcass. Departement of Animal and Poultry Science. University of Guelph.

[3] North. M. O. 1992. Commercial Chicken Production Manual. Third Edition. Avi Publishing Co. Inc. Westport. Connecticut.

[4] Resnawati, H. 2004. Cuts Carcass Weight And Fat Abdomen Broiler chickens fed Flour Containing Earthworm (Lumbricus Rubellus). www.peternakan.litbang.deptan.go.id. Accessed July 2, 2008.

[5] Rezaei, M., H. N. Moghaddam, J. Pour Reza and H. Kermanshahi. 2004. The Effects of Dietary Protein and Lysine Levels on Broiler Performance, Carcass Characteristics and $\mathrm{N}$ Excretion. International Journal of Poultry Science 3 (2) : 148 - 152.

[6] Rizal, Y. 2006. Poultry Nutrition Sciences. Andalas University Press. Padang.

[7] Siregar, Z., Supriadi, dan E. Mirwandhono. 2003. Quality Improvement Palm Kernel Oil-cake through fermentation by Rhizopus oligosporus and Nopcozime Supplementation to Broiler. Faculty of Agriculture, University of North Sumatra. Medan.

[8] Siregar, Z Dan Mirwandhono, E. 2004. Evaluation of the Utilization of Palm Kernel Meal Fermented by Aspergillus Niger hydrolyzate Chicken Feather Meal And Mineral Supplementation in Broiler Zn. USU digital library. University of North Sumatra.

[9] Sjofyan, O., Aulani' am, Irfan, O dan Surisdiarto. 2001. Changes and Protein Content of Organic Matter on the fermentation of cassava waste and Chicken Manure Mixture. Journal of Biological Sciences. Vol 13(1). P. 1-7.

[10] Steel, RCD. And JH.Torrie. 1995. Principles and Procedures of Statistics. PT Gramedia. Jakarta

[11] Sukaryana, Y. 2001. Effect of Fermentation of Palm Oil-cake with Trichoderma viride on Change of Chemical Composition, bioconversion efficiency, and the Food and metabolizable energy in broiler chickens. Thesis. Padjadjaran University Graduate Program. Bandung.

[12] Sukaryana,Y. 2007. Optimizing Utilization of Palm Kernel Meal, Gaplek, and cassava waste through fermentation technology with Moulds of Different As Poultry Feed Ingredients. Competitive Research Grant.

[13] Tillman, A.D., Reksohadiprodjo, S., Prawirokusumo, S., dan Lebdosoekojo, S. 1998. Basic Animal Nutrition Science. Gadjah Mada University Press. Yogyakarta. 